\title{
POR UM ENSINO DE HISTÓRIA INDÍGENA EM MATO GROSSO: O POVO CHIQUITANO NA FRONTEIRA BRASIL/ BOLÍVIA
}

\author{
FOR A TEACHING OF INDIGENOUS HISTORY IN MATO GROSSO: \\ THE CHIQUITAN PEOPLE ON THE BRAZIL / BOLIVIA BORDER
}

Leticia Antônia de Queiroz ${ }^{1}$

Renilson Rosa Ribeiro ${ }^{2}$

\begin{abstract}
RESUMO: A partir do questionamento dos estereótipos e padrões forjados em torno do conceito de "índio genérico", o presente artigo investe na análise das imagens das populações indígenas presentes na "tradição" narrativa eurocentrada dos livros didáticos de História no Brasil, para em seguida adentrar as tramas da história do povo Chiquitano na fronteira Brasil-Bolívia, em Mato Grosso.
\end{abstract}

Palavras-chave: Ensino de história. Livro didático. História indígena. História do Brasil. Povos chiquitanos. Mato Grosso.

ABSTRACT: Based on the questioning of the stereotypes and patterns forged around the concept of "generic Indian", the present article invests in the analysis of the images of the indigenous populations present in the Eurocentric narrative "tradition" of the textbooks of History in Brazil. plots of the history of the Chiquitano people on the BrazilBolivia border in Mato Grosso.

Keywords: History Teaching. Textbooks. Indigenous History. History of Brazil. Chiquitano peoples. Mato Grosso.

1 Mestre em Educação pela Universidade do Estado de Mato Grosso (Unemat). Professora da rede estadual de ensino do Estado de Mato Grosso SEDUC-MT. e-mail: leticia.cuiaba@gmail.com

2 Doutor em História Cultural pela Universidade Estadual de Campinas (Unicamp), com estágio pós-doutoral em Educação pela Universidade de São Paulo (Usp). Professor Associado do Departamento de História da Universidade Federal de Mato Grosso (UFMT). e-mail: rrenilson@yahoo.com 
[...] a diferença é sempre uma relação: não se pode ser 'diferente' de forma absoluta; é-se diferente relativamente a alguma outra coisa, considerada precisamente como 'não-diferente'. Mas essa 'outra coisa' não é nenhum referencial absoluto, que exista fora do processo discursivo de significação: essa 'outra coisa', o 'nãodiferente', também só faz sentido, só existe, na 'relação de diferença' que a opõe ao 'diferente'. Na medida em que é uma relação social, o processo social, o processo de significação que produz a 'diferença' se dá em conexão com relações de poder. São as relações de poder que fazem com que a 'diferença' seja avaliada negativamente relativamente ao 'não-diferente'. Inversamente, se há sinal, sem dos termos da diferença é avaliado positivamente (o 'não-diferente') e o outro, negativamente (o 'diferente'), é porque há poder (SILVA, 2001, p. 87).

\section{A "invenção" da categoria "índio genérico", uma narrativa contra a história}

Para a historiadora Maria Regina Celestino de Almeida (2003), a historiografia brasileira e também o ensino de história incorporaram, ao longo do tempo, a máxima proferida por Francisco Adolfo de Varnhagen de que os índios eram povos na infância, sem história. Nestas interpretações as populações indígenas

[...] aparecem, grosso modo, como atores coadjuvantes, agindo sempre em função dos interesses alheios. Aliás, não agiam, apenas reagiam a estímulos externos sempre colocados pelos europeus. Tem-se quase a impressão de que estavam no Brasil à disposição desses últimos, que se serviam deles à vontade, descartando-os qu ando não mais necessários: teriam sido úteis para determinadas atividades e inúteis para outras, aliados ou inimigos, bons ou maus, sempre de acordo com os interesses e objetivos dos colonizadores (ALMEIDA, 2003, p. 27). ${ }^{3}$

Tais representações, em diferentes contextos históricos de ensino e aprendizagem têm se feito presentes na literatura infanto-juvenil, nos textos didáticos, na iconografia, nas músicas, nos filmes, na fala docente e nos discursos celebrativos do 19 de abril - "Dia do Índio". ${ }^{4}$

3Cf. também Castro (2002, p. 183-264); Almeida (2010).

4De acordo com Luís Donisete Benzi Grupioni (1998, p. 481), "o dia do Índio foi comemorado no Brasil, pela primeira vez, em 1944. Desde então, sempre em abril, o dia 19 é dedicado ao índio. É provável que todos nós tenhamos alguma lembrança de ter tomado parte de comemorações 
Ao longo da vida escolar, crianças e jovens têm forjando a ideia do índio como uma unidade étnica padrão, não se atentando para as diferenças e particularidades dos diferentes povos que habitavam (e habitam) o que mais tarde seria conhecido como Brasil. Geralmente estas populações são apresentadas como as personagens que esperam a chegada das embarcações da História, trazidas pelos europeus. Todo o período anterior à chegada de Cristóvão Colombo (1492) e Pedro Álvares Cabral (1500) é rotulado de pré-história.

Nos livros didáticos, por exemplo, o capítulo das grandes navegações e descobrimentos constitui geralmente o momento da "entrada" do Brasil no palco da História, ao menos aquela idealizada pelo pensamento eurocêntrico. As narrativas didáticas diversas vezes dão a entender que antes da chegada dos portugueses o lugar era um imenso "espaço vazio", ocupado por "selvagens", sem nenhuma noção de civilização, denominados de povos "pré-históricos" (RIBEIRO, 2006, p. 54-59).

Na história do continente americano, a definição de Pré-História tem como referência tradicional o período anterior à chegada dos europeus ao continente, em fins do século XV. Os europeus batizaram a sua presença na América de "História" e destinaram para todo o período anterior o termo "Pré-História", ainda que atualmente se saiba que se usava a escrita no Novo Mundo já antes da vinda dos colonizadores:

Os maias, a civilização que se desenvolveu no México e na América Central, possuíam uma escrita muito elaborada, embora usada quase sempre em contexto religioso, ainda por ser totalmente decifrada. Os incas usavam cordas para registrar eventos, chamados quipos. Na verdade, muitos povos americanos tinham sistemas de registros comparáveis à escrita, como os povos nambiquaras e tupis - na forma de pinturas corporais, adereços e decorações de objetos -, como propôs recentemente o americanista britânico Gordon Brotherston. Apesar disso, generalizou-se o uso do termo Pré-história da América para todo o período anterior a 1492, data da chegada de Colombo no continente (FUNARI; NOELLI, 2002, p. 13).

A história indígena, assim como do povo africano, ainda é pensada como um ramo, ou melhor, um afluente, para usar uma metáfora do naturalista bávaro

deste tipo quando frequentávamos os bancos escolares, ou de ver estampados nos jornais matérias sobre os índios no dia 19 de abril". 
Karl Friedrich Philipp von Martius, no imenso rio civilizatório conhecido como Brasil, construído pelos portugueses. Só se pensa a história destes "outros" quando se agregam pacífica ou forçosamente ao projeto europeu no Novo Mundo. Eles são sempre o diferente, o estrangeiro, o exótico - a imagem invertida do espelho do que seria a civilização: europeia, masculina e branca, que trouxe para o "resto" - Ásia, África e América - a Fé (cristianismo), a Lei (Estado) e o Rei (Autoridade). ${ }^{5}$ Com base nesta tríade, a história destes povos tem sido composta e ensinada nos bancos escolares ao longo dos séculos XIX e $\mathrm{XX}{ }^{6}$

Estas imagens genéricas se fazem presente tanto no universo dos livros didáticos quanto em outros lugares de produção e circulação de saber: TV, cinema e literatura. Basta lembrarmos as imagens estereotipadas apresentadas do índio em novelas como Uga-Uga, A Lua Me Disse e Alma Gêmea, produzidas por emissoras de TV brasileiras nos últimos tempos. Segundo Naine Terena de Jesus (2007, p. 100),

A questão do conhecimento e reconhecimento dos povos indígenas no país ainda é visivelmente deturpada. As escolas urbanas ainda parecem pouco preparadas para apresentar aos seus alunos os povos indígenas do país, confundindo o índio brasileiro com os indígenas americanos apresentados em filmes e comerciais. $\mathrm{Na}$ minha profissão de radialista na cobertura de algumas comemorações nacionais esses equívocos são perceptíveis. Exemplo dessa experiência ocorreu em um episódio na cidade de Cuiabá, no mês de abril de 2007. Em homenagem ao dia do índio (19 de abril), uma professora das séries iniciais entregou um desenho com a representação de um índio para as crianças

5 De acordo com Maria Aparecida Bergamaschi (2010, p. 156), "o termo civilização expressa o lugar da pessoa distinta nas novas relações sociais que se configurou na sociedade da modernidade europeia, em geral vinculado à corte, em contraposição ao homem simples, que, na sua forma mais extrema, assume o lugar do selvagem, imagem também identificada com o indígena. De forma mais geral, podemos deduzir que o sentimento de civilização predominante no Ocidente nos últimos três séculos parte de uma autoimagem de superioridade diante das demais sociedades. Esse sentimento tem correspondência em alguns setores das elites não europeias, como no caso brasileiro, em que a perspectiva de progresso, de desenvolvimento, se colocou na esteira do processo civilizatório europeu. Nesse modelo de civilização não cabe o índio, não cabe o negro e não cabe o mestiço, referências que as elites, de distintas formas, quiseram apagar, encobrir, entulhar, deformar, tanto na história, como na escola". Para uma discussão sobre o conceito de civilização, cf. Todorov (1996); starobinski (2001).

6 Para entender as representações sobre as populações indígenas no pensamento ocidental, cf. Raminelli (1996). 
pintarem. A figura era típica de um índio americano, com roupas e adornos semelhantes aos utilizados nos filmes Hollywoodianos.

Feitos esses apontamentos iniciais, vejamos como a temática indígena em linhas gerais tem sido abordada nos livros didáticos de História no Brasil, para em seguida adentrarmos as tramas da história do povo chiquitano na fronteira Brasil-Bolívia, em Mato Grosso.

\section{Ensinar/aprender história indígena no século XXI ainda com os pés fincados nas teses do século $\mathrm{XIX}^{7}$}

Se consultarmos a produção didática produzida no Brasil, desde a fundação do Colégio Pedro II, em 1837, principalmente com a publicação do Licoes de História do Brasil (1861-1907), do professor e romancista Joaquim Manuel de Macedo, no período imperial, passando pelos clássicos manuais escolares de Joao Ribeiro, Joaquim Silva, Borges Hermida até a coleção História e Vida, dos irmãos Nelson e Claudino Pilleti, nos anos 1980, perceberemos como esses autores, em diferentes contextos, construíram a imagem dos povos indígenas a partir de um padrão narrativo, considerando de forma estática e a-histórica, cinco fios temáticos: origens e classificação, relações sociais e familiares, usos e costumes, primeiros contatos e influencias na chamada cultura brasileira.

Amparados nas afirmações de cronistas, jesuítas e viajantes, esses autores procuraram descrever aspectos gerais da cultura e comportamento indígena mais no sentido de uma etnografia do que propriamente uma abordagem histórica. Mesmo as classificações tribais eram feitas com base nos modelos de von Martius, Karl von Steinen e dos próprios jesuítas e colonizadores. Os índios do litoral eram denominados de tupi e do interior de tapuia. A diversidade de etnias, quando apenas listada, era sumariamente ignorada nesses enredos da história. O cerne da questão era estabelecer uma visão generalizada dessas populações a partir do seu modo. Etnias sem nome, sujeitos sem história. Para Luís Donisete Grupioni (1998, p. 483), os livros didáticos de História operavam com a categoria de um índio genérico, ou seja, aquele índio que vivia nu na mata, morava em ocas e tabas, enfeitava-se com cocar e penacho na cabeça,

7Essa seção tem como referência a pesquisa publicada em Ribeiro (2004); Ribeiro (2010).

História \& Ensino, Londrina, v. 26, n. 1, p. 78-112, jan./jun. 2020 
cultuasse Tupã e Jaci e que falava tupi. O enredo dessas narrativas didáticas da "história" dos povos indígenas assentava-se na busca de referencias comuns que permitissem identificar ou nomear um grupo de seres humanos de raça indígena, "raça cor de cobre" ou "raça americana".

Segundo Everardo Rocha (1984, p. 31), a constância com que podemos apreender o emprego de certo tipo de frase curta, direta, sintética e incisiva tem sido uma das marcas na estruturação dos textos didáticos. Por exemplo, um sem-número de frases típicas como "os indígenas geralmente andavam nus", "gostavam de se adornar com colares, braceletes, brincos de pequenos ossos ou de madeira", "os índios viviam da caça e da pesca", "eram nômades" expressões retiradas dos livros didáticos de Joaquim Silva e Borges Hermida - e outras variações possíveis e imagináveis encontramos com frequência nestes livros, criando uma noção de unidade entre diferentes grupos étnicos. Dessa maneira, as diversas etnias - amarradas no termo problemático de "tribos" eram definidas como um todo homogêneo, absolutamente igual aos aspectos que se desejava nelas enfatizar, demarcando uma raça.

Nesses livros didáticos, os indígenas eram definidos também, muitas vezes, por contraste, ou seja, no que eles diferiam do padrão de civilização: europeu, branco, cristão, civilizado. Podemos identificar esta estratégia no livro didático de Borges Hermida ([19--]) e, também, dos irmãos Pilleti e Pilleti (1991). Lembremos a referência à expressão: "sem fé, sem lei e sem rei", que aparece com diferentes nuances no corpo desses textos.

Apesar de destacarem as diferenciações, os autores dos livros didáticos, ao longo de gerações, optaram por tratar os nativos como se fossem um todo homogêneo e como se a generalização fosse a melhor forma de estudá-los, ou melhor, dos alunos entenderem sua história. Fizeram a escolha pelo binômio analítico índio $\mathrm{x}$ branco, selvagem $\mathrm{x}$ civilizado, inferior $\mathrm{x}$ superior, primitivo $\mathrm{x}$ avançado, colonizado $x$ colonizador, vencido $x$ vencedor, subsenvolvido $\mathrm{x}$ desenvolvido.

A impressão final que deveria ficar na mente dos alunos seria aquela do índio numa mesma disposição e idêntica visão de mundo. Em suma, uma só cultura, uma só raça e um mesmo homem vivendo apenas na medida em que o 
diferia do elemento colonizador, este de múltiplas faces, mas ainda assim uma raça superior - o padrão de medida do nível de civilização da humanidade.

Na cultura ocidental, de acordo com Jurandir Freire Costa (1986, p. 106),

[...] a brancura transcende o branco. Eles [os brancos] indivíduos, povo, nação ou Estado brancos podem 'enegrecer-se'. Ela, a brancura, permanece branca. Nada pode macular esta brancura que, a ferro e fogo cravou-se na consciência negra como sinônimo de pureza artística, nobreza estética, majestade moral, sabedoria científica etc. O belo, o bom, o justo, e o verdadeiro são brancos. O branco é, foi e continua sendo a manifestação do Espírito, da Ideia, da Razão. O branco, a brancura, são os únicos artífices e legítimos herdeiros do progresso e desenvolvimento do homem. Eles são a cultura, a civilização, em uma palavra, 'a humanidade.

A diferença era elaborada com base na noção de atraso, primitivismo, préHistória. Havia uma série de expressões que poderia ser intercambiável ao se referir aos primeiros habitantes da "quarta parte do mundo": selvagem, bárbaro, índio, indígena, primitivo, primário, antropófago, não-civilizado. Nomes que encobriam outras múltiplas identidades, faces de grupos que foram enterrados numa expressão identitária, classificatória, hierarquizada com fins de conquistar, dominar, controlar e civilizar ou exterminar - física e discursivamente (SILVA, 2000).

Nomes, terminologias com data de nascimento e finalidades, que nos pareciam ou nos faziam parecer tão naturais, eram empregados como se fosse impossível pensar nas populações deste continente antes de 1492 sem uso destas palavras. Para Norma Telles (1992, p. 80-82), era como se esses povos passassem a existir somente no momento em que o navegador genovês Cristóvão Colombo os batizou de "índios".

Nas produções didáticas mais recentes inspiradas nas novas propostas dos Parâmetros Curriculares Nacionais (PCN) e da historiografia contemporânea, identificamos a preocupação em trabalhar com os alunos a ideia de como os sujeitos históricos - individuais ou coletivos - e mitos são historicamente construídos e a necessidade de se abordar temáticas relacionadas à diversidade étnico-racial e cultural (cf. MARTINS, 2009, p. 153-167). ${ }^{8}$

8Segundo Maria Celestino de Almeida (2010, p. 15), ao longo praticamente do século XX, "a cultura dos chamados "povos primitivos", vista como pura e imutável, era objeto de investigação dos antropólogos preocupados em compreendê-la em suas características originais e autênticas. 
Dentro desta perspectiva, por exemplo, os professores Andrea Montellato, Conceição Cabrini e Roberto Catelli Junior, na coleção didática História Temática, no volume "Diversidade Cultural e Conflitos", publicada em 2000, procuraram mostrar as articulações entre a criação de mitos e a memória histórica, enfatizando os usos políticos e ideológicos no enaltecimento de heróis por povos e nações, e também o compromisso da educação histórica com o ensino das diferentes culturas e modos de vidam que sobreviveram ou sobrevivem lado a lado num determinado espaço ao longo do tempo. ${ }^{9}$

No caso do capítulo dedicado ao mito e à memória histórica, ao tratarem do caso de Tiradentes, por exemplo, os autores analisaram sua imagem a partir do contexto da Inconfidência Mineira, mas também como parte da invenção do panteão nacional republicano. Zumbi dos Palmares foi outra personagem a ganhar relevo na narrativa das resistências escravas ao cativeiro no período colonial. Os autores da coleção História Temática tiveram a preocupação de demonstrar como a sua história tem sido apropriada como símbolo da luta contra o racismo pelo movimento negro.

A valorização dos heróis nacionais, segundo os autores da coleção História Temática, no ensino de História é tão marcante que podemos perceber sua presença no nosso cotidiano nomeando cidades, ruas, praças, bairros e monumentos. Sua presença é tão acentuada nestes lugares de memória que parece que seria impossível narrar a história do Brasil sem eles. O Brasil não existiria sem seus heróis (MONTELLATO; CABRINI; CATELLI JUNIOR, 2000, p. 15).

Processos históricos de mudança por eles vividos não eram valorizados por pesquisadores interessados em desvendar a lógica e o funcionamento da cultura entendida de forma essencialista, isto é, como fixa, estável e imutável. Além disso, os chamados povos primitivos eram considerados isolados e sem história. Moviam-se com base em suas tradições e mitos considerados também a-históricos".

9Não pretendemos com este exemplo afirmar que esta seja a forma correta de abordar a temática indígena na sala de aula, mas indicar sugestões de transformações e av*anços na abordagem da história e da cultura destes povos no ensino de História e, em especial, na produção didática. Outras obras e experiências positivas produzidas desde então podem ser citadas nesta direção, mas extrapolaria os limites deste artigo. Para uma reflexão aprofundada sobre os desafios e possibilidades da história indígena na educação básica, cf. Zamboni; Bergamaschi (2013, p. 1-9); Bergamaschi (2010, p. 295-304); Silva (2015). 
Quanto à noção de mito de origem presentes na formação da identidade dos povos e nações, os autores procuraram abordar os diferentes usos do conceito - seja como origem, seja como crença em lugares fabulosos, em diversas culturas ao longo do tempo na Europa, África e América. No caso Brasil, abordaram a origem da agricultura entre o povo Karajá pelo mito de Tahira-Can, a estrela vespertina, e da existência de uma "terra sem mal" por parte dos índios Tupi e Guarani, que estaria situada do outro lado do oceano ou no centro da Terra.

A reflexão acerca da construção histórica dos heróis e símbolos nacionais ou mitos fundadores, em pesquisas recentes como a realizada por Thais Nívia de Lima e Fonseca, no livro História \& Ensino de História (cf. FONSECA, 2003), têm apontado para a necessidade de se pensar os sujeitos na História não centrados apenas em personagens que realizaram feitos individuais ou tidos como heroicos, como autoridades ou figuras políticas - em sua maioria de origem europeia, branca e cristã.

As tramas da história não podem ser entendidas como sendo dependente do destino de poucos, de façanhas ou vontades individuais de lideranças, em que pouco se destaca a dimensão coletiva das lutas por mudanças ou da resistência exercida por grupos em defesa de seus direitos, como por exemplo, a populações indígenas presentes no continente americano.

$\mathrm{Na}$ parte dedicada ao (des)encontro entre culturas, os autores dedicaram especial atenção à presença dos povos indígenas em diferentes contextos da história do continente americano, trazendo articulações entre presente e passado e estabelecendo diálogos entre América e Europa e Brasil e América.

Procurando desmistificar a categoria "índios" como "um nome generalizante que não consegue traduzir a complexidade e a diversidade dessas culturas" presente no continente, a coleção História Temática abordou essas sociedades humanas com termos como nações ou povos para designar um determinado grupo indígena. Nesse sentido, os autores exploram as diferentes histórias, crenças, costumes e modos de vida das populações nativas da América (MONTELLATO; CABRINI; CATELLI JUNIOR, 2000, p. 70).

Ao contrário das consagradas imagens e adjetivações de um "índio padrão", vemos emergir nas páginas do livro didático informações sobre a história e 
cultura dos povos Apinayé, Bororo, Krenak, Nambikwara, Karitiana, Munduruku, Kaiapó, Yanomami, Xavate, Cinta Larga, entre outros. Ao lado destas temáticas, há discussões acerca dos conflitos, dominação e formas de resistência durante a conquista e colonização, da escravidão e catequese de indígenas, da demarcação das reservas indígenas e a disputa pela terra, das lutas contra a discriminação e preconceito racial e da agenda contemporânea pela busca de reconhecimento e valorização dos modos de vida destas populações.

Por meio de uso de obras de referência no assunto, literatura, iconografia, artigos em jornais e revistas e entrevistas, partindo de um viés temático para pensar e ensinar a história, os autores procuraram abordar os povos indígenas como sujeitos históricos, fugindo do estereótipo de vítimas, submissos, selvagens ou exóticos - condenados ao desaparecimento ou à aculturação.

Essa perspectiva de compreensão da história e dos seus atores, adotada pela coleção História Temática para os povos indígenas, contrapõe-se àquela imagem tradicional "martelada" em corações e mentes infanto-juvenis nos bancos escolares pelas narrativas e imagens presentes nos livros didáticos:

Houve um tempo em que a História era doutrinação e se destinava, antes de tudo, a formar e manter os valores da nacionalidade, e a disciplina acabava se transformando no espaço cultural mais adequado à reprodução desses sentimentos. $\mathrm{Na}$ escola, a pátria era grande, a raça era forte, os governadores menos alguns tiranos - amavam o povo e eram amados por ele, não havia sangue, nem lutas, nem desavenças [...]. Todos, afinal, se entendiam na doce harmonia de um magnífico paraíso tropical, desenhado graças à ação dos excepcionais heróis imortalizados no panteão da pátria (PINSKY, 2009, p. 47).

Nesse sentido, os autores do referido livro didático aproximam-se de uma concepção de cultura como produto histórico, dinâmico e flexível para compreender as sociedades indígenas. Para Maria Celestino de Almeida (2010, p. 23),

[...] a ideia de que os grupos indígenas e suas culturas, longe de estarem congelados, transformam-se através da dinâmica de suas relações sociais, em processos históricos que não necessariamente os conduzem ao desaparecimento, permite repensar a trajetória histórica de inúmeros povos que, por muito tempo foram considerados misturados e extintos. Não é o caso de desconsiderar a violência do processo de conquista e colonização. A mortalidade 
foi altíssima, inúmeras etnias foram extintas e os grupos e indivíduos que se integraram à colônia ocuparam os estratos sociais mais inferiores, sofrendo preconceitos, discriminações e prejuízos incalculáveis. Apesar disso, no entanto, encontraram possibilidades de sobrevivência e souberam aproveitá-las.

Os sujeitos históricos, como apresentam os próprios Parâmetros Curriculares Nacionais para o ensino fundamental e médio (PCN), presentes no cotidiano escolar brasileiro desde 1997, seriam vistos como todos aqueles que, em determinados contextos históricos, mostraram suas especificidades, sendo líderes de lutas para transformações ou permanências na sua realidade, atuando em grupo ou de forma isolada. Eles seriam trabalhadores, mulheres, crianças, indígenas, africanos, escravos, camponeses, religiosos, intelectuais, políticos entre outros.

Nestas narrativas sai o nevoeiro da mística e da celebração dos heróis nacionais e entra em cena o exercício reflexivo e crítico sobre a ação social de indivíduos, grupos ou classes sociais, por vezes, à margem das páginas dos livros didáticos de História.

No caso do questionamento e transformações das imagens das populações indígenas nas recentes produções didáticas, destaca-se que este fato não seria apenas fruto dos avanços teóricos e metodológicos da história e da antropologia e dos novos currículos de História, signatários destas inovações na abordagem do tema na área de saber, mas também da ação política dos movimentos representativos de defesa da história e da cultura indígena no Brasil. Para Edson Machado de Brito (2009, p. 67), essas transformações

[...] representam a força da resistência indígena e o esforço de setores democráticos da sociedade brasileira em favor do reconhecimento do direito dos povos indígenas enquanto povos diferenciados, que participam da comunidade nacional, mas que mantém estreitos laços históricos com os povos que ocupavam as terras atualmente denominadas de Brasil, antes da chegada dos colonizadores portugueses. Aceitar essa situação histórica é respeitar a diversidade cultural expressa por mais de 180 línguas faladas atualmente no território brasileiro, por exemplo.

A valorização da história, da cultura e de personagens indígenas, defendida por esses grupos reivindicatórios e pela produção acadêmica na área nas últimas décadas, pode ser traduzida na formulação e aprovação a promulgação da Lei n. 
11.645/08 (BRASIL, 2008), que torna obrigatória as aulas de história e cultura dos povos indígenas para os alunos do ensino fundamental e médio, que substitui, complementando, a Lei n. 10.639/03, que já previa a inclusão da temática africana e afro-brasileira no currículo das escolas. ${ }^{10}$

A Lei n. 11.645/08, ao reforçar e evidenciar questões presentes na Lei de Diretrizes e Bases da Educação Nacional (BRASIL, 1996) e nos PCN, tem posto um incontornável e necessário desafio a ser enfrentado pelos cursos de formação de professores e, especialmente, pela prática pedagógica do profissional da História a cerca de abordagens historiográficas e estudos interdisciplinares que rediscutem a herança colonial de pobreza, privação de direitos e falta de escolaridade da população africana e afro-brasileira, como salienta Leila Leite Hernandez (2005, p. 13), e ainda, conforme enfoque de Maria Regina Celestino de Almeida, a "participação de indígenas como atores coadjuvantes, agindo sempre em função do interesse alheio" (ALMEIDA, 2003, p. 27).

Para começo de conversa, do ponto de vista da prática pedagógica em sala de aula, Luis Donisete Grupioni (1998, p. 42) sugere que o caminho a trilhar seja "rever os nossos conhecimentos, perceber nossas deficiências, buscar novas formas e novas fontes de saber".

De acordo com Maria Aparecida Bergamaschi, além das inquietações provocadas pela obrigatoriedade do estudo da história e da cultura indígenas, a referida lei permite

[...] um diálogo etnocultural respeitoso, cuja condição básica é o reconhecimento dos povos originários como interlocutores legítimos, embasando a interação no respeito aos seus conhecimentos e saberes, considerando sua história, sua cultura e os modos próprios de viver. $E$, nesse sentido, é importante considerar o que professores, lideranças e intelectuais indígenas têm a dizer-nos [...]. Penso que esse é o movimento: reconhecer que precisamos apreender a história dos povos indígenas e debruçar-nos sobre ela, considerando a necessidade das suas vozes, escrevendo e contando suas histórias (BERGAMASCHI, 2010, 163)

Tendo em vista a leitura das representações dos povos indígenas fabricadas pelos autores de livros didáticos de História, procurando compreender como e

10Para compreender o histórico da construção da Lei n. 11.645/08, cf. Bergamaschi (2010, p. 151166). 
porque eles criaram seus modelos de interpretação, ao escrever suas versões didáticas para a história nacional, e as demandas e necessidades da implementação de uma história indígena em consonância com uma história plural e voltada para a formação de cultura antirracista, torna-se vital empreendermos movimentos de imersão nas narrativas históricas sobre os diferentes grupos étnicos indígenas presentes no território brasileiro/mato-grossense. Tal preocupação formativa tem a finalidade de subsidiar a prática docente na construção de aulas e projetos de trabalho voltados para o diálogo entre história, cultura e diversidade.

Nada mais emblemático para entender a história indígena em contexto escolar do que trazer o povo Chiquitano como personagens dessas tramas identitárias na busca de visibilidade a afirmação. Esse ato de escrita reflexiva procura trilhar o caminho de se criar e ensinar histórias que não podem ser esquecidas porque dizem muito sobre o quanto somos desconhecidos de nós mesmos. Para além do diagnóstico do estado da arte sobre o tema no contexto da historiografia e ensino de história, assumimos o compromisso de trazer outras possibilidades de trabalho em sala de aula.

\section{História(s) do Povo Chiquitano em Mato Grosso: a fronteira Brasil- Bolívia ${ }^{11}$}

Para abordarmos a história chiquitana apresentamos uma reflexão baseada em pesquisa bibliográfica e etnográfica realizada na comunidade indígena da aldeia Vila Nova Barbecho, Município de Porto Esperidião, em Mato Grosso no período de 2011 a 2012. O recorte analisado visa contribuir para a compreensão das relações históricas e sociais das sociedades indígenas em Mato Grosso, evidenciando as relações conflitivas da luta do povo Chiquitano que os inserem numa dinâmica permanente pela conquista dos territórios de ocupação ancestral. Apoiada no levantamento das fontes documentais de origem diversas sobre a longa história de contato que remonta ao século XVI. Constatamos que durante quatro séculos as populações indígenas brasileiras foram submetidas ao extermínio sistemático. A análise foi balizada segundo a literatura pertinente, leis

11Essa seção tem por referência a pesquisa publicada em Queiroz (2013).

História \& Ensino, Londrina, v. 26, n. 1, p. 78-112, jan./jun. 2020 
específicas, documentos da Fundação Nacional do Índio (FUNAI), entrevistas com lideranças do povo Chiquitano, professores, indigenistas.

Para Aloir Pacini (2012b, p. 1), "na atual fronteira geopolítica do Brasil com a Bolívia, no estado de Mato Grosso vive a etnia indígena Chiquitano, falante da língua isolada vesüro ${ }^{12 " .}$. Dados históricos dão conta de que o povo Chiquitano ${ }^{13}$ é "[...] um amálgama de povos ${ }^{14}$ que ocupavam desde as margens do rio Guaporé no Brasil, até as planícies bolivianas" (SILVA, 2008, p. 130). Ao longo do tempo, "[...] muitos grupos indígenas desapareceram ou receberam outras denominações, houve também aqueles que integraram a outras etnias que possuíam afinidades socioculturais" (SILVA, 2008, p. 131).

Segundo os estudos realizados pela antropóloga Joana Aparecida Fernandes Silva $\left(2012^{a}\right.$, p. 120),

Há uma variedade de estabelecimentos Chiquitanos; aldeias (localmente identificadas como 'comunidades de bugres'), agrupamentos em beiras de estradas (resultante de processos de expulsão de terras tradicionais antes do reconhecimento da FUNAI - Fundação Nacional do Índio), estabelecimentos juntamente com os destacamentos militares. Há, também, uma população de Chiquitanos urbanizados nas cidades de Porto Espiridião, Cáceres e Vila Bela da Santíssima Trindade, cujo número se desconhece.

Assim, podemos considerar que os Chiquitano, habitantes da faixa fronteiriça entre Brasil e Bolívia, constituíram-se historicamente como guardiões dessa fronteira. No entanto, o Estado-nação brasileiro nunca reconheceu devidamente esse grupo indígena. Nos discursos oficiais, a presença indígena na faixa de fronteira e a demarcação de suas terras são vistas como ameaças à soberania nacional.

12Segundo nota n. 2 do autor Pacini (2012b, p. 2) "Os Chiquitanos em geral no Brasil são bilíngues (português e espanhol), porém, em muitos casos também trilíngues, falantes da língua chiquitana vesüro, preconceituosamente dita linguará".

13Para Roberto Tomicha Chaparú (2008), Chiquitano é um termo abrangente e se refere a todos os povos reduzidos pelos jesuítas nos séculos XVII e XVIII, que, após a expulsão destes da América Espanhola, em 1754, tiveram modificações importantes tanto na sua configuração social como nos processos históricos (apud SILVA, 2012a, p. 125-126).

14 "Os cerca de vinte e cinco povos originais que foram aldeados pelos jesuítas, em sua maioria, perderam suas especificidades culturais, ou seja, desapareceram enquanto povos singulares, dando lugar aos Chiquitos, termo que os religiosos adotaram para designar os grupos sob o domínio missioneiro (SILVA, 2012a, p. 126). 
$\mathrm{Na}$ literatura antropológica a língua falada atualmente, tanto no Brasil quanto na Bolívia, com alguma variação dialetal, é o chiquito, resultado do processo histórico relatado anteriormente, onde os 'chiquitos' eram a maioria e conviviam com outros grupos minoritários, como os Aruac, Chapakura e Otuque, que deveriam aprender o chiquito como língua de comunicação geral, um linguará15 (ALBÓ, 1991). Estima-se que exista hoje na Bolívia cerca de 40.000 falantes, o que torna a língua chiquitano a quarta língua mais falada no país. (GISBERT, 2007 apud GARCIA, 2010, p. 67-68). Os estudos de Silva e Moreira da Costa (2001 apud GARCIA, 2010, p. 67)

[...] afirmam que os Chiquitano constituem um sistema cultural próprio, acima de rótulos de bolivianos ou brasileiros. Para os autores estimam que no lado brasileiro exista cerca de 2.500 habitantes, dividido em 22 comunidades. Além disso, existem cerca de 900 indivíduos considerados Chiquitano dispersos nas cidades de Vila Bela, Cáceres e Porto Esperidião.

A dinâmica da produção da vida faz com que cada comunidade se organize e busque alternativas de sobrevivência em relação à natureza disponível, aos bens materiais e imateriais possíveis, e nisso vão se produzindo como grupo específico, diferenciando-se e identificando-se com seus parentes mais próximos, com os outros grupos populacionais da região e com as possibilidades socioeconômicas em cada momento histórico. O trabalho na terra com a roça, a pesca, a coleta de frutos, nem sempre são suficientes para a sobrevivência das famílias, especialmente quando seus territórios são apropriados por fazendeiros, sitiantes e pelas novas organizações urbanas. Com isso, desde o período colonial, o povo Chiquitano teve que se submeter ao trabalho para outros como uma forma de sobrevivência.

Com a expulsão dos jesuítas da América, os Chiquitano inicialmente trabalharam nas fazendas e, algum tempo depois, foram recrutados para a Guerra do Chaco (1932-1935). Com o fim da guerra, passaram a desenvolver tarefas em seringais, na construção da via férrea entre Santa Cruz e Corumbá e na recuperação do setor pecuário. Só em 1953 é que eles foram libertados da servidão na Bolívia (DUNCK-CINTRA, 2006, p. 271).

150s estudos de Pacini (2012a) apontam que Linguará era uma maneira de desqualificar a língua geral dos Chiquitano, mas a expressão foi incorporada por eles para designar a língua. 
Para a autora, os Chiquitano que estavam do lado brasileiro ainda permaneceram no regime de escravidão nas fazendas. Identificamos, assim, que o povo Chiquitano é o mesmo em ambos os lados da fronteira, como ocorre em outras fronteiras brasileiras cujos povos vivem tradicionalmente em territórios divididos pela organização das nações-estados. Nos documentos e narrativas dos seus anciões eles não se reconhecem como remanescentes, mas como povo que sempre habitou e habita esta região de fronteira.

"A fronteira entre o Brasil e a Bolívia é a mais extensa dos dois países, com 3.423 quilômetros, entre os estados de Mato Grosso, Mato Grosso do Sul, Rondônia e Acre" (GARCIA, 2010, p. 105). No entanto, há que se considerar que outras nações indígenas também habitam as fronteiras brasileiras, além do povo Chiquitano.

De acordo com Silva (2012a, p. 126) "Até finais da década de 1990 não havia uma separação (a não ser pela distância geográfica, no caso dos que moravam mais distantes) e tampouco uma percepção forte por parte dos Chiquitano do que era Brasil ou Bolívia."

No entanto, ainda segundo a autora, "[...] o exército de ambos os lados marcava concretamente a nacionalidade brasileira ou boliviana: roupas, fisionomias e língua eram sinais diacríticos que indicavam onde alguém estava situado, se na Bolívia ou no Brasil" (SILVA, 2012a, p. 126). Nota-se, diante das afirmações da autora, que para os Chiquitano não havia diferença entre estarem no Brasil ou na Bolívia, para eles tratava-se de um só território e uma só cultura.

Podemos considerar que para os Chiquitano o reconhecimento fronteiriço não se aplicava à fronteira política entre Brasil e Bolívia, mas às fronteiras étnico-culturais com outros grupos indígenas que habitavam a região, conforme apresentado no mapa expresso na Figura 1. 
Figura 1 - Mapa etno-histórico

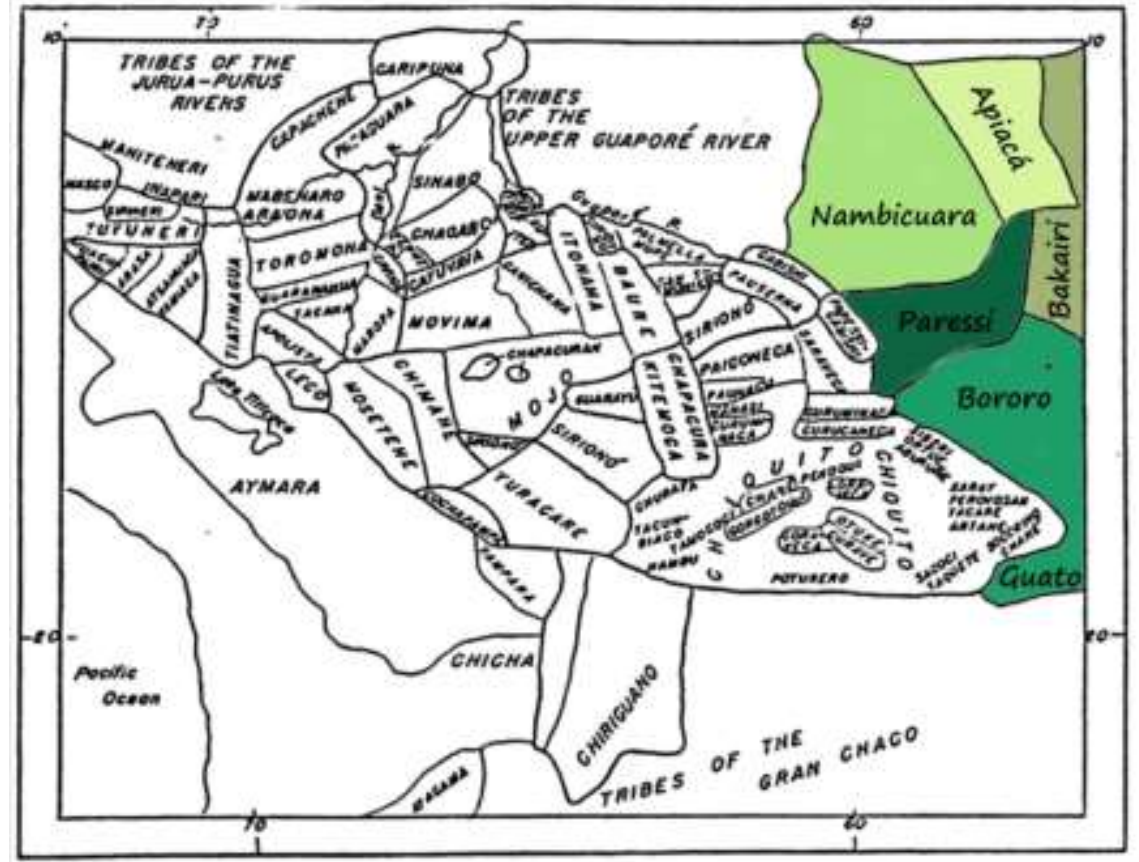

Fonte: Métraux (1948 apud SILVA, 2008, p. 129). ${ }^{\mathbf{1 6}}$

No Estado de Mato Grosso, "[...] em finais da década 1990 prosseguia um processo que havia se iniciado em 1976 pelo INCRA - Instituto Nacional de Colonização e Reforma Agrária, titulação de fazendas e de expulsão dos Chiquitano [...]" (SILVA et al. 1998, p. 133). Segundo a autora, "A movimentação desse povo ocorria em direção às cidades próximas da região, ou para as bordas das fazendas agora reconhecidas como propriedade privada." (SILVA et al. 1998, p. 134).

De acordo com Silva (2006) "[...] em 1987, o fotógrafo Mário Friedlander enviou um relatório para a FUNAI e ao $\mathrm{CIMI}^{17}$, informando a situação precária em que viviam as famílias reconhecidas na região de Cáceres como bugres [...]" (apud GARCIA, 2010, p. 69). Conforme relata o autor, o fotógrafo "[...] informa que essas famílias, que não eram reconhecidas pelo governo brasileiro como indígenas, estavam correndo risco de sobrevivência física e cultural diante do avanço da ocupação econômica da região [...]" (SILVA, 2006 apud GARCIA,

160 mapa apresenta as fronteiras étnico-culturais reconhecidas pelo povo Chiquitano com os povos: Guató, Bororo, Paresi, Nambicuara (Nambikwara). Os destaques coloridos no mapa foram feitos pela pesquisadora, demarcando os povos indígenas nas fronteiras com os Chiquitano.

17 Segundo Pacini (2012a, p. 16), em resposta, Mario Bordignon, coordenador do CIMI/MT na época, observou "Os fazendeiros estão grilando e desmatando a área, desalojando os índios. (21/12/1989) arquivo CIMI/MT. 
2010, p. 69-70). Consideramos, pelos estudos realizados, que esse relatório foi fundamental para que a FUNAI passasse a investigar a situação desse grupo étnico e, a partir de então, desencadeasse todo o processo de seu reconhecimento.

O grupo de Trabalho, instituído pela FUNAI em 1995 e coordenado pela Antropóloga Denise Maldi, da Universidade Federal de Mato Grosso-UFMT, em serviço de vistoria na região, esclarece que as comunidades de Chiquitano, exemplificando com as de São Fabiano, Barbecho e Acorizinho, já estavam historicamente e culturalmente estruturadas ${ }^{18}$, porém sujeitos a fracionamentos a partir de um continuado processo de pressão e espoliação. (COSTA, 2004, p. 4)

Os estudos realizados pela antropóloga Maldi Meireles ${ }^{19}$ faz referência às comunidades estudadas e apresenta dados de que elas sempre ocuparam a região, vivendo de acordo com suas práticas culturais tradicionais, plantando suas roças, fabricando suas cerâmicas e dançando o Curussé no período do Carnaval. Até então, Maldi Meireles (1989) já havia realizado outras pesquisas antropológicas na região da fronteira entre o Brasil e a Bolívia e identificado a existência dos Chiquitano. Com os estudos complementares realizados por solicitação da FUNAI, evidencia-se a existência de uma conexão entre as famílias identificadas por Mário Friedlander e o povo Chiquitano, mesmo que, considerando as demandas das relações históricas de esbulhos de seus territórios por colonizadores, essas famílias não usassem o etnônimo Chiquitano como forma de identificação.

Esta mesma "invisibilidade" dada pelo governo brasileiro aos povos indígenas reforçava a condição necessária aos grupos de Chiquitano de estarem ocultos, que, por conta das perseguições de que foram vítimas durante vários anos, pode ser considerada como uma estratégia de sobrevivência física (cf.

18 MALDI, Denise. Vistoria na Fazenda Nacional de Casalvasco. Administração Regional de Cuiabá. Fundação Nacional do Índio. Ordem de Serviço 134,1995, p. 17. (nota do autor, n. 10, p. 4).

19 Denise Maldi Meireles é citada por Moreira da Costa (2006) como Maldi e por Almeida (2011), como Meireles, no entanto, ambos se referem à mesma autora, responsável pelos estudos solicitados pela FUNAI em 1995, que reconhece, a partir destes, a identidade Chiquitano das comunidades indígenas, registradas pelas lentes do fotógrafo Mário Fridlander na região de fronteira com a Bolívia, no Brasil. 
também SILVA, 2011b). No entanto, a cultura imaterial se manteve evidente, fato constatado em todos os relatórios de identificação deste grupo indígena.

\begin{abstract}
Desta forma, foi Meireles quem estabeleceu no contexto indigenista e acadêmico, a conexão entre estas famílias e o povo Chiquitano. Isso não quer dizer que estas comunidades não se viam como pertencentes a este povo, e sim, que não utilizavam cotidianamente, por diversos motivos, o etnônimo Chiquitano para identificarem (GARCIA, 2010, p. 72).
\end{abstract}

As estratégias de invisibilidade do Chiquitano eram reforçadas à medida que esse povo entendia ser desnecessária sua autoidentificação. Segundo os estudos de Cardoso de Oliveira (2006):

Afirma que o etnônimo é essencial ao exterior, mas secundário no interior dos territórios próprios ou nas etnias. Isso quer dizer que nas relações cotidianas nas famílias pertencentes a este povo, não era necessário se pensar como pertencimento ao Povo Chiquitano (apud GARCIA, 2010, p. 72).

No entanto, esta necessidade da autoidentificação surge nas relações entre as famílias identificadas como Chiquitano e a FUNAI, instituição gestora da política indigenista brasileira que "[...] requer dos indígenas um posicionamento claro sobre seu vínculo etno-histórico, demonstrável a partir do fortalecimento de um etnônimo específico" (GARCIA, 2010, p. 72).

O autor afirma que, mesmo com as evidências da presença de Chiquitano no Brasil, constatadas por meio dos relatórios de Meireles, novos estudos só tiveram início em 1998, e que "[...] não partiram de demandas das famílias Chiquitano, mas sim de empreendimento econômico." (GARCIA, 2010, p.72).

O desenvolvimento regional demanda novas cidades e vilas na região, provocando uma dinâmica de interação étnica que vai contribuir para a invisibilidade do Chiquitano, ao mesmo tempo em que provoca a expulsão de um grande número deles para viverem em territórios urbanos.

Segundo Moreira da Costa (2006, p. 15), com o crescimento econômico do estado de Mato Grosso e a crescente instalação de indústrias vindas de diferentes regiões do país, aumenta a demanda de consumo de energia e consequentemente a busca por novas alternativas energéticas. A Multinacional 
Gasocidente Eron ${ }^{20}$ é implementada com sede em Cuiabá para atender essa demanda, aproveitando a energia disponível e a do gás natural produzido na Bolívia. Como o projeto se tratava de um empreendimento com altos investimentos, foi realizado um estudo para o licenciamento ambiental. Uma das condições contratuais imposta aos executores para o licenciamento da obra foi a realização do estudo sobre os impactos ambientais, e logo de início revelou-se na região a presença de bugres $^{21}$.

Esta demanda desencadeia os estudos realizados por Silva et al. (1998), como "Estudo das comunidades indígenas na área de influência do Gasoduto Bolívia - Mato Grosso", evidenciando que até então, mesmo após o estudo realizado por Meireles, a questão Chiquitano ${ }^{22}$ ainda não era reconhecida no meio acadêmico e na Instituição Gestora da Política Indigenista no Brasil, a FUNAI.

Com os estudos realizados nesse novo enfoque "ambiental" os territórios foram demarcados pelas famílias e comunidades que o ocupavam e passam a ser reconhecidos como territórios indígenas do Brasil, mesmo que este reconhecimento não tenha ainda sido consolidado oficialmente como direito e legalizado pelo Estado.

Silva (2008), em suas pesquisas, constatou que os Chiquitano em Mato Grosso vivem na região sudoeste do estado, em terras localizadas nos municípios de Cáceres, Porto Esperidião e Vila Bela da Santíssima Trindade. Segundo a autora a "[...] aparente dispersão dos Chiquitano entre vários municípios obedece a uma lógica de agrupamentos que se baseiam em relações de parentesco, casamentos, redes de amizade e de trocas" (SILVA, 2008, p. 121). A partir do Relatório Circunstanciado de Identificação e Delimitação da Terra

200 Gasoduto Bolívia - Mato Grosso parte da Cidade de Santa Cruz de la Sierra, atravessa o território boliviano, passa por Cáceres e segue em direção à capital do estado de Mato Grosso. A Usina Termelétrica está situada em Cuiabá, capital do estado. Sua relevância nesta pesquisa se dá por ter sido possível, a partir dos estudos dos impactos ambientais, a realização e o reconhecimento dos povos tradicionais da região, no caso, os Chiquitano com os quais estamos trabalhando.

21Bugres é o termo que, segundo Moreira da Costa (2006), se refere a uma designação pejorativa, que a população da região da fronteira dava aos índios da região. Já, o mesmo termo para Santos (2006) "[...] a categoria bugre apresenta-se de forma ressignificada, usada de forma ambivalente para designar aqueles que têm características fenotípicas indígenas que não negam sua identidade, mas marcam a diferença por não serem índios aldeados".

22Para Moreira da Costa (2006), o termo "Chiquitano" é uma designação genérica atribuída pelos europeus, no século XVI, para as diversas etnias que habitavam a província de Chiquitos. 
Indígena Portal do Encantado povo Indígena Chiquitano, que a autora elaborou para a FUNAI (2004), as comunidades Chiquitano são organizadas no lado brasileiro da fronteira, da seguinte forma: Núcleo de Limão; Núcleo de Fortuna; Osbi; Núcleo São Sebastião; São Fabiano; e a população urbana dos Chiquitano, que vive em Cáceres, Porto Esperidião e Vila Bela, conforme podemos visualizar na Figura 2:

Figura 2 - Mapa das comunidades Chiquitano no Brasil

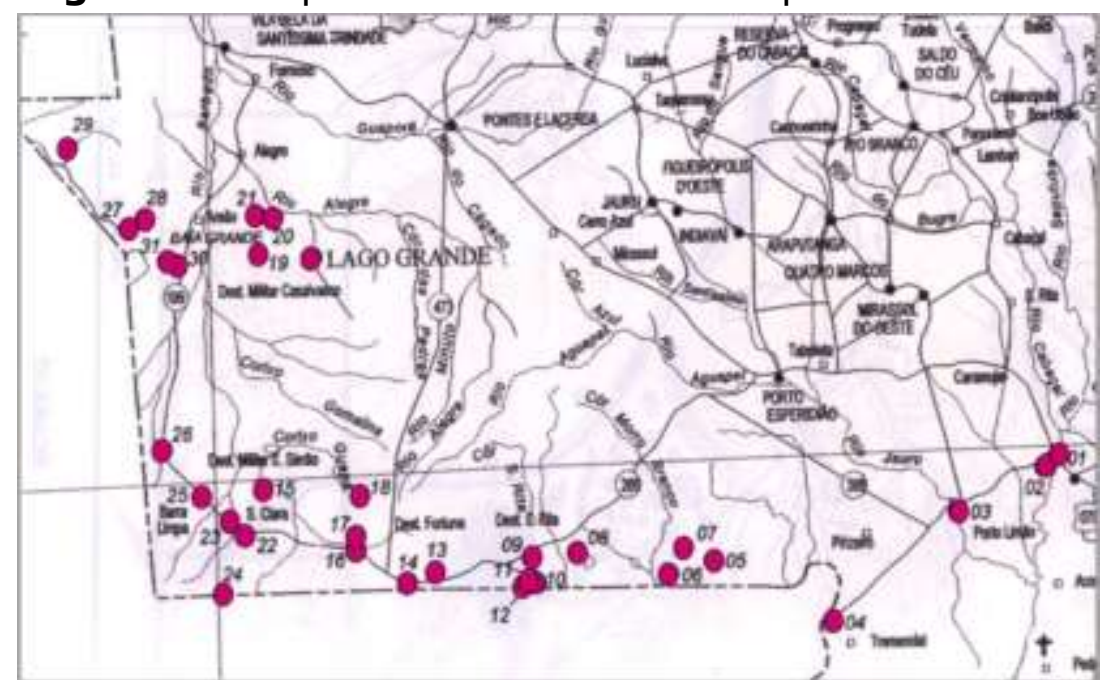

Fonte: FUNAI (2000 apud COSTA, 2006, p. 212). ${ }^{23}$

Os Núcleos, definidos pela autora como núcleos familiares, se constituem em várias comunidades ou aldeias.

No núcleo de São Fabiano, estão incluídas Asa Branca e Vila Nova. São Fabiano, um assentamento do INCRA, tem cerca de vinte e duas famílias de Chiquitano, que não se identificam oficialmente como tais, mas pela origem histórica é possível perceber que têm a mesma história dos demais estabelecimentos estudados. Um dos motivos que os levam a evitar a autoidentificação de índios, nos explicaram, seria porque Ihes disseram que caso a Fundação Nacional do Índio (FUNAI) os identificasse como tais, teriam que andar nus e não poderiam mais fazer suas roças tradicionais. Ao lado do destacamento militar de Asa Branca vivem algumas famílias de Chiquitanos, com terras também tituladas pelo INCRA. Asa Branca tem casas dispostas ao longo de duas pequenas ruas, com pouco espaço para agricultura. Vila Nova, próxima a São Fabiano, é constituída de uma população que foi expulsa da aldeia de Barbecho, limítrofes à Bolívia. Atualmente é um pequeno

23 Os destaques coloridos do mapa foram feitos pela pesquisadora, demarcando as comunidades Chiquitano no Brasil. 
agrupamento de pessoas, suscetíveis às pressões e ameaças de um fazendeiro que pretende que as terras de Barbecho sejam suas (SILVA, 2008, p. 123).

\section{No território de ocupação ancestral Aldeia Vila Nova Barbecho}

Em suas narrativas, as lideranças tradicionais do povo Chiquitano afirmam que desde seus antepassados, sempre viveram naquele lugar.

[...] o ambiente colonialista [...] está relacionado, portanto, a um conjunto de relações sociais de poder, linguagens, práticas e saberes que marcam a relação do Estado e de amplos segmentos da sociedade nacional para com as minorias étnicas. Está presente especialmente em situações sócio-históricas decorrentes do avanço das frentes pioneiras, sobretudo nos campos econômico, político, social e cultural. Tem a ver ainda com esbulhos de territórios de ocupação tradicional de populações indígenas e quilombolas, processos de territorialização, discriminação étnicoracial e outras formas de violência, inclusive a física, contra povos e comunidades etnicamente distintos em relação à sociedade nacional (EREMITES DE OLIVEIRA; PEREIRA, 2010, p. 191, grifo do autor).

A antropóloga Joana Aparecida Fernandes Silva (2008), analisando a produção da imprensa e as campanhas políticas de negação da etnicidade, afirma que políticos de grande influência no estado de Mato Grosso, utilizando da imprensa, regional e nacional que depende dos favores do estado, promovem campanhas com informações sem fundamentos científicos, oriundas de fontes não confiáveis para confundir a população local de que na região não existiam comunidades indígenas.

Estas campanhas evidenciam a invisibilidade do povo Chiquitano assumida pelo governo brasileiro por conveniência, pois, como explicitado nos documentos históricos analisados (e também os relatos dos habitantes da região), os Chiquitano habitam territórios mato-grossenses desde a metade do século XVII, portanto, a questão territorial não se trata de um mero debate acadêmico. A pesquisadora comprova nos seus estudos que tais documentos registram a presença do povo Chiquitano na fronteira do Brasil com a Bolívia desde 1748, 
inclusive vivendo na aldeia Vila Nova Barbecho, portanto, num período anterior à "fundação da Capitania de Mato Grosso"24.

Em Moreira da Costa (2006), nos relatos de Barbosa de Sá25 pode-se evidenciar a presença de "Chiquitos" ainda na primeira metade do século XVIII, quando este participa de comitiva que percorreu a região:

[...] à época, morador da Vila Real do Bom Jesus de Cuiabá, informa que, devido à catequese efetuada dos índios no alto curso do rio Cuiabá, efetuada pelos jesuítas espanhóis, a Câmara decidiu enviar uma comitiva às missões de Chiquitos para, dentre outros intentos, dissuadir a fuga de índios e estabelecer relações comerciais. O percurso da comitiva que atravessou os rios Paragoia e Jauru no lugar chamado as pitas adonde acharaó seguido dos missionários até alcançar a Missão de San Rafael, morada de diversas etnias atraídas para a redução religiosa (SÁ, 1975 apud COSTA, 2006, p. 2)

Para o autor, a presença do povo Chiquitano em terras brasileiras é registrada também pelo Bispo que percorre a região em atendimento aos matogrossenses da região, como expresso abaixo:

O Bispo D. Luiz Marie Galibert, durante os trabalhos itinerantes da pastoral, em 1922, pôde constatar que a população fronteiriça de Cáceres a Vila Bela é composta, em geral de Chiquitos, ocasião que teve a oportunidade de visitar diversas comunidades Chiquitano ao ministrar os sacramentos católicos (COSTA, 2006, p. 2, grifo do autor).

O representante da igreja católica identifica a população da fronteira utilizando o etnônimo Chiquitano, o que evidencia o reconhecimento de sinais diacríticos que identifica e diferencia este grupo indígena visitado do restante da população fronteiriça. Segundo os autores que estudam o povo Chiquitano, alguns sinais diacríticos são reconhecidos nos documentos e nos registros etnográficos que definem a etnicidade chiquitano. Entre eles, o Curussé (PACINI,

240 processo de desocupação do território que atualmente constitui o Mato Grosso ocorreu nesse período. Em 1718 chegaram os bandeirantes à atual capital Cuiabá, cujo encontro histórico com os índios coxiponés (ancestrais dos bororo atuais) marcou um novo processo de avanços territoriais em busca de riquezas e mão-de-obra para a então Capitania de São Paulo (GRANDO, 2004, p. 81).

25Esses relatos de Barbosa de Sá foram publicados na obra: Barboza de Sá (1975). 
2008), e a religiosidade imposta no processo de colonização e disputa territorial entre Espanha e Portugal, entre outros.

\begin{abstract}
Moreira da Costa (2006) refere-se ainda como parte dos documentos que registram a presença do Chiquitano de Barbecho, o registro feito 'pelo Major Frederico Rondon ao percorrer, em 1936, a zona fronteiriça mato-grossense', da seguinte forma: 'Vivendo entre duas nações civilizadas e a ambas servindo com sacrifício do seu suor e do seu sangue, os Chiquitos têm direito de esperar de ambos o acatamento às tradições arraigadas em seus espíritos de neófitos da civilização cristã.' (COSTA, 2006, p. 3-4, grifo do autor).
\end{abstract}

Segundo o autor, o Major Rondon, durante uma missão de inspeção "[...] situa a comunidade de Barbecho, próxima de Las Petas e de Acurizal, esta última incluída no interior da Terra Indígena Portal do Encantado, identificada e delimitada pela FUNAI" (COSTA, 2006, p. 3), em 2005:

Las Petas fica à margem direita do Tarumã, em território boliviano, a duas léguas de Barbecho[...]. Partindo do Tarumã, nossa estrada é balisada pelas rancharias do Barbecho e do Boqueirrão, distanciadas uma da outra de meia légua aproximadamente[...]. São moradores Chiquitanos (vivendo, segundo a expressão boliviana) e brasileiros que vivem de lavoura e criação (COSTA, 2006, p. 3-4).

A região da fronteira era desconhecida na cartografia militar e para isso era necessário o registro detalhando da localização do território brasileiro, assim como as populações nativas e regionais nele localizados. Como registram os documentos acima, podemos confirmar que o povo Chiquitano da Vila Nova Barbecho, como também afirmam as lideranças da aldeia, sempre povoou a região onde atualmente reivindicam a demarcação oficial de suas terras.

O nome Barbecho viria a se impor também na toponímia regional, passando a designar a Serra do Barbicho, local onde encontra-se a comunidade Chiquitano de Vila Nova Barbecho, assinalado na cartografia do Ministério do Exército, datada de 1975 (COSTA, 2006, p. 4).

O que chama a atenção nos dados para a cartografia é o fato de as aldeias Chiquitano serem consideradas marcos demarcatórios do território nacional. Esse levantamento aponta para a existência de vários grupos indígenas na região, ele 
usa o etnônimo Chiquitano; em outras palavras, já naquele período, por mais que os territórios tenham sido negados, eles são visíveis e utilizados para registrar uma população local em território nacional, pelo Exército Brasileiro.

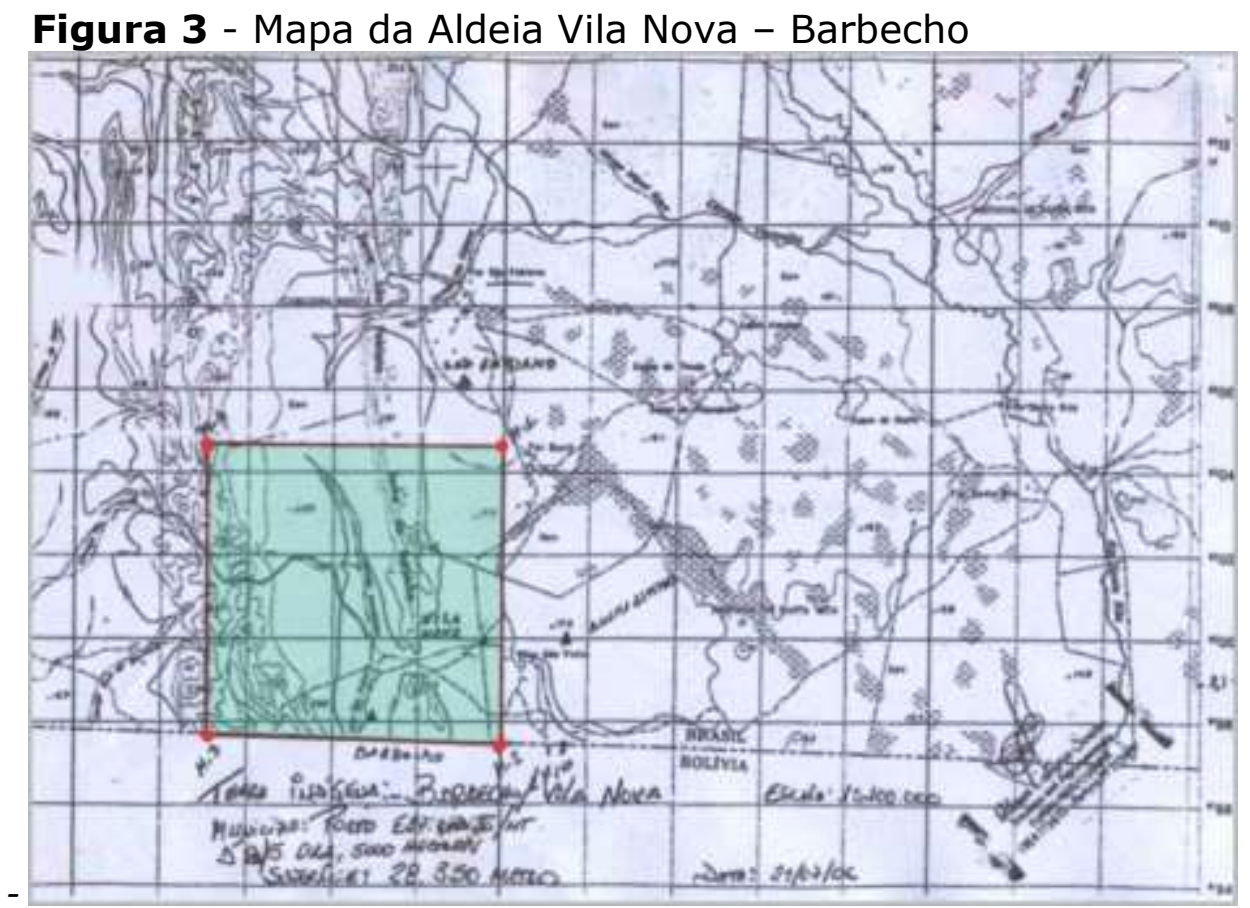

Fonte: FUNAI (2006 apud COSTA, 2006, p. 6). ${ }^{26}$

Evidenciamos assim, a partir dos documentos oficiais cedidos pela FUNAI/ERA/CBA ${ }^{27}$, e da literatura estudada, que a aldeia Vila Nova Barbecho, é um território que tradicionalmente vem sendo ocupado pelo povo Chiquitano.

Segundo Moreira da Costa (2006, p. 4):

Vila Nova nasceu desse processo, como extensão da Comunidade de Barbecho, após a pressão da Fazenda São Pedro que dificultava a permanência dos índios em seu interior, como consta no Estudo das Comunidades Indígenas na área de influência do Gasoduto Bolívia-Mato Grosso.

No entanto, mesmo que documentos históricos confirmem a presença dos Chiquitano na Terra Indígena Barbecho, para estudos de reconhecimento e

\footnotetext{
26Destaque no mapa feito pela pesquisadora para evidenciar a aldeia Vila Nova Barbecho na faixa de fronteira Brasil-Bolívia.

27FUNAI (2006)
}

História \& Ensino, Londrina, v. 26, n. 1, p. 78-112, jan./jun. 2020 
demarcação, o grupo sempre viveu em constantes pressões, como nos relata a professora Saturnina Urupê Chuê:

\begin{abstract}
Nossa aldeia sempre chamou Barbecho, com a chegada do fazendeiro dizendo ser o dono das terras precisamos pedir autorização para ele para mudarmos a aldeia de lugar devido onde morávamos já estava improdutivo. Para autorizar mudança o fazendeiro condicionou que a nova aldeia deveria chamar Vila Nova, seu intuito de tirar o nome de Barbecho é fragilizar a luta do povo. Mas os anciãos da aldeia não aceitaram somente esse nome de Vila Nova eles acataram, mas com o Barbecho na frente para que este nome não desaparecesse, pois é o nome tradicional do lugar. Como continuamos morando na mesma terra não é necessário mudar de nome. Hoje é reconhecida como aldeia Vila Nova Barbecho. ${ }^{28}$
\end{abstract}

A partir do diálogo entre o pesquisador Secchi e a professora Saturnina, podemos perceber a estratégia usada pelo fazendeiro para tirar a identidade do povo Chiquitano, ao tentar mudar o nome do lugar onde tradicionalmente habitam. No entanto, o grupo tem suas formas de sobrevivência étnica, aceitando o nome imposto pelo opressor, desde que acrescido do nome de significado ancestral, reforçando a pertença étnica do povo e mostrando para as novas gerações que aquele espaço é território Chiquitano, onde seus ancestrais ali viveram.

Não significa, no entanto, que pelo fato de serem reconhecidos pelos órgãos oficiais, estes são visibilizados nos direitos constitucionais, especialmente em relação à terra. Como ocorre em outros territórios de fronteira, seja com outros países ou com as "fronteiras" impostas pelos capitalistas atuais (fazendeiros, comerciantes, políticos etc.), o Chiquitano vive em um "ambiente colonialista".

Como afirmam Eremites de Oliveira e Pereira (2010, p. 190):

\begin{abstract}
Caracterizamos como ambiente colonialista o cenário político marcado por várias formas de violências e tentativas de dominação contra minorias étnicas, sitiadas e constrangidas por diversos mecanismos de sujeição, como por exemplo, a imposição feita aos indígenas para se comunicarem em segunda língua, o português.
\end{abstract}

28Diálogo entre Secchi e Chuê, em 21 fev. 2013. 
Para os autores, ao serem colocados nesta situação de violência simbólica também, estas comunidades enfrentam a dificuldade em acompanharem e se defenderem com seus direitos dentro do "sistema jurídico" que é "completamente estranho às regras de convivência que vigoram em suas comunidades", pois para eles:

Trata-se, ainda, de saberes, práticas e poderes que aglutinam indivíduos e coletividades da sociedade envolvente (fazendeiros, instituições ruralistas, jornalistas, setores da imprensa que dependem de favores do Estado etc.), bem como agentes do Estado imponderados com cargos que possuem (delegados de polícia, procuradores, juízes, assistentes judiciários, parlamentares, governantes etc.). Não obstante, eles têm o contraponto em povos e comunidades tradicionais - e seus aliados (organizações não governamentais, setores de universidades, Ministério Público Federal, intelectuais etc.) que reivindicam direitos territoriais, apesar de encontrarem enorme dificuldade em dominar os códigos em que são obrigados a expressarem os argumentos que podem referendar seus direitos (EREMITES DE OLIVEIRA; PEREIRA, 2010, p. 190).

O povo Chiquitano foi expulso dos seus territórios tradicionais pela expansão do capitalismo, em nome do desenvolvimento do estado de Mato Grosso. Pela modernização da pecuária e o avanço do agronegócio esse grupo vive sérios problemas, passando por necessidades, vivendo em uma pequena área cercado por latifúndio.

Segundo os estudos realizados por Grando (2004, p. 83):

São vários os exemplos recentes na nossa história a demonstrar que os valores que justificaram as guerras justas contra os indígenas no século XVI estão presentes no século XX. Para explorar a borracha nas regiões mato-grossenses de Aripuanã e Alta Floresta, os seringalistas empreitaram novas guerras na década de sessenta. Os registros mais cruéis nessa região foram contra os Cinta-Larga: para limpar a área a ser explorada, foram usados dinamites e alimentos contaminados jogados em sobrevoos sobre as aldeias, mas o crime da Chacina do Paralelo 11 foi o mais cruel.

É nesse contexto de grandes latifúndios e ambientes colonialistas que o Chiquitano se encontra, onde os interesses da sociedade dominante, representada pelos fazendeiros da região divide o mesmo espaço social com esse povo que sobreviveu à "ocupação" de grupos de migrantes vindos de todas as 
regiões do país, se instalando em suas terras e usurpando da força de trabalho, tanto de homens quanto de mulheres, reforçando a desigualdade social com base em valores etnocêntricos e preconceituosos, desconsiderando os verdadeiros donos das terras.

De acordo com os estudos de Pacini (2012b, p. 65, grifo do autor):

[...] a aldeia Chiquitana de Vila Nova Barbecho (Brasil) que possui muitas raízes de seus membros no pueblo misional Santa Ana na Bolívia. Vila Nova Barbecho não é a única aldeia que sofre os desmandos da Justiça Federal, mas é um caso típico: uma Liminar do Juiz Federal determinou 325 hectares para esta comunidade e, em 06/12/2012, outro juiz decidiu impor novamente a cerca em tono de 25 hectares para liberar o restante das terras para o gado da Fazenda São Pedro.

O espaço que o Chiquitano vive atualmente é insuficiente para a plantação de suas roças e também para a manutenção de outras práticas culturais. Segundo Pacini (2012b, p. 3) "[...] a demarcação de um território Chiquitano deve considerar muito mais que a terra simplesmente, mas este elemento intrinsecamente associado à água e aos seus significados". A demarcação dos territórios Chiquitano se torna muito mais importante quando se constata que é por meio da terra reconhecida que são garantidas "[...] outras práticas dos Chiquitano, entre elas as festas, as roças e tudo o que exige de recursos naturais para que aconteça a vida em comunidade segundo os costumes Chiquitano". (PACINI, 2012b, p. 3).

Consideramos que a situação em que o Chiquitano vive não é favorável em muitos aspectos à sua sobrevivência, no entanto as relações de tensão étnicos e culturais têm gerado fronteiras, não uma fronteira geopolítica, mas uma fronteira que "[...] pode ser compreendida como tensão entre os países, entre fazendeiros e indígenas e mesmo entre os próprios Chiquitano." (PACINI, 2012b, p. 4).

No entanto, a sobrevivência étnica do Chiquitano é reconstituída por meio da alegria e manifestada nos momentos festivos que acontecem todos os anos na festa do Curussé. Para Pacini (2012b, p. 4), no "[...] Curussé (ou carnavalito) ou festas dos padroeiros são desfeitos os conflitos entre os opostos e se 
conectam as fronteiras a fim de que todos os Chiquitano se encontrem para a grande festa onde a norma básica é 'pular e dançar".

É justamente por isso que se torna importante discutir, no âmbito do Mercosul, o lugar que ocupam os povos indígenas nos discursos da cúpula da organização, espaço político e econômico integrado pelo Brasil e pela Bolívia, países onde há grande concentração de povos indígenas, em especial de Chiquitano, objeto deste estudo.

Para o Chiquitano, conforme narrativas dos anciãos em documentos históricos, que confirmam serem eles habitantes da faixa fronteiriça BrasilBolívia, não há, em suas memórias, fronteiras entre os Estados-nações. Suas terras sempre foram contínuas, de um só povo. O que de fato sempre existiu foram as fronteiras étnicas e culturais com os povos indígenas vizinhos, fato confirmado nas relações políticas econômicas e culturais que foram estabelecidas na região.

\section{Considerações finais}

Documentos históricos provam que o Chiquitano da aldeia Vila Nova Barbecho, habita as terras, onde vivem atualmente, desde 1748, ou seja, antes da fundação da capitania de Mato Grosso. No entanto, a sociedade no seu entorno os denomina de "bugres", ou de bolivianos, reforçando os esbulhos dos seus territórios, pois se não são brasileiros não têm direito às terras. Os atuais fazendeiros da região são considerados pelo poder público como os verdadeiros donos das terras, muito valorizadas devido à expansão do agronegócio nessa região do estado.

Para o governo brasileiro não existe terra indígena na região, e se não há terra indígena não há índios, com esse discurso o INCRA loteou a vendeu as terras dos Chiquitano para os grandes empreendimentos agropecuários, objeto de cobiça de políticos e comerciantes da região.

No entanto, como estratégia de sobrevivência étnica, o grupo de Chiquitano brasileiros aceita essa invisibilidade, mas educa as suas crianças conforme a cultura dos seus ancestrais para a manutenção da identidade étnica do grupo. Uma educação que é marcada no corpo, fato comprovado neste ensaio. 
Podemos então concluir que, mesmo diante de toda natureza de espoliação, esbulho e violência simbólica, as lideranças tradicionais do povo Chiquitano mantêm suas práticas culturais ancestrais, educando as gerações mais novas por meio de uma educação marcada no corpo e que acontece no cotidiano das aldeias, nos momentos ritualizados como é o caso do Curussé, e também nas festas de santos, nas romarias, entre outros espaços, sejam eles familiares ou coletivos.

Ao trazermos as histórias do povo Chiquitano, no contexto da fronteira Brasil/Bolívia, como uma possibilidade dentre outras narrativas para a construção de uma proposta de ensino de História, convidamos educadores e alunos a trilhar percursos novos para pensar a diversidade, a diferença e pluralidade cultural - tendo por referência que fazer história é estar constantemente em movimento, entre lugares, conhecendo o outro e a si mesmo. ${ }^{29}$

\section{Referências}

ALMEIDA, Maria Regina Celestino. Identidades étnicas e culturais: novas perspectivas para a história indígena. In: ABREU, M.; SOIHET, R. (org.). Ensino de história: conceitos, temáticos e metodologia. Rio de Janeiro: Casa da Palavra, FAPERJ, 2003. p. 27-37.

ALMEIDA, Maria Regina Celestino. Os Índios na história do Brasil. In: ENCONTRO NACIONAL DOS PESQUISADORES DO ENSINO DE HISTÓRIA - AMÉRICA LATINA EM PERSPECTIVA: CULTURAS, MEMÓRIAS E SABERES, 9., 2011, Florianópolis. Anais Eletrônicos [...]. Florianópolis: UFSC: ABEH: ANPUH, 2011.

ALMEIDA, Maria Regina Celestino. Os índios na história do Brasil. Rio de Janeiro: Ed. FGV, 2010.

BERGAMASCHI, Maria Aparecida. Povos indígenas e ensino de história: a lei ${ }^{0}$ 11.645/2008 como caminho para a interculturalidade. In: BARROSO, V. L. M et al. (org.). Ensino de história: desafios contemporâneos. Porto Alegre:

Exclamação: ANPUH-RS, 2010. p. 151-166.

BRASIL. Lei n. 9.394, de 20 de Dezembro de 1996. Estabelece as diretrizes e bases da educação nacional. Brasília: Presidência da República, 1996.

29Merecem destaque as pesquisas desenvolvidas sobre a história e cultura chiquitana por Giovani José da Silva. Cf. Silva (2009); SILVA (2011a). 
- RCNEI - Referencial Curricular Nacional Educação Indígena. Brasília, DF, Ministério da Educação, 1998.

. Processo n. 2000.36.01.0011484-2 Justiça Federal de Mato Grosso, Subseção Judiciária de Cáceres - MT de 22.09.2008. Fica definido um Módulo Rural do INCRA, definido em 25 ha. Para uso exclusivo dos indígenas, é assegurado o acesso da comunidade em toda área objeto do litígio, ressalvada as instalações da Fazenda São Pedro.

- Ofício n. 1041/2006/SEPOD/EMO- Justiça Federal de Mato Grosso, Subseção Judiciária de Cáceres-MT de 22.08.2006, comunicando à FUNAI que o Juiz Julier Sebastião da Silva, acata um pedido feito através de liminar onde resguarda a posse que a Comunidade Chiquitano Vila Nova exerce sobre as terras que tradicionalmente ocupam, em área rural do Município de Porto Esperidião.

BRITO, E. M. O ensino de história como lugar privilegiado para o estabelecimento de um novo diálogo com a cultural indígena nas escolas brasileiras de nível básico. Fronteiras. Dourados, v. 11, n. 20, p. 59-72, jul./dez. 2009.

COMUNIDADE CHIQUITANO. Carta endereçada à Secretaria de Educação do Estado de Mato Grosso, Cuiabá [...]. Chiquitano: Comunidade da Vila Nova Barbecho, 23 jan. 2009.

CASTRO, Eduardo Viveiros de. A inconstância da alma selvagem e outros ensaios de antropologia. São Paulo: Cosac \& Naify, 2002.

COSTA, José Eduardo F. Moreira da. A coroa do mundo: religião, território e territorialidade Chiquitano. Cuiabá: EdUFMT, 2006.

COSTA, José Eduardo F. Moreira da. Breve histórico dos Chiquitanos. In:

PEREIRA, J. C. V. Enciclopédia ilustrada de Mato Grosso. Cuiabá: Buruti, 2004. p. 97-98.

COSTA, Jurandir Freire. Violência e psicanálise. 2. ed. Rio de Janeiro: Edições Graal, 1986.

DUNCK-CINTRA, Ema Marta. Vozes silenciadas: um estudo sociolinguístico dos Chiquitano no Brasil. Revista Signótica, Goiânia, v. 18, n. 2, p. 269-282, jul./dez. 2006.

EREMITES DE OLIVEIRA, Jorge; PEREIRA, Levi M. Reconhecimentos de territórios indígenas e quilombolas em Mato Grosso do Sul: desafios para a antropologia social e a arqueologia em ambientes colonialistas. In: AGUIAR, Rodrigo Luiz Simas de; EREMITES DE OLIVEIRA, Jorge; PEREIRA, Levi M. (org.). Arqueologia, etnologia e etno-história em iberoamérica: fronteiras, cosmologia, antropologia em aplicação. Dourados: EdUFGD, 2010. p. 185-208. 
FONSECA, Thais Nívia. História \& ensino de história. Belo Horizonte: Autêntica, 2003.

FUNAI - FUNDAÇÃO NACIONAL DO ÍNDIO. Memorial descritivo de delimitação: denominação terra indígena/Barbecho/Vila Nova aldeias integrantes: Barbecho e Vila Nova - grupo indígena Chiquitano. Cuiabá: Funai Administração Executiva Regional, 2006. Cartografia 1 - Terras Indígenas - MT\01.011.2 - Chiquitano Vila Nova Barbecho.

FUNARI, Pedro Paulo A.; NOELLI, Francisco Silva. Pré-história do Brasil. São Paulo: Contexto, 2002.

GARCIA, Thiago Almeida. No chão da escola é diferente?: a educação escolar indígena em duas comunidades Chiquitano na fronteira Brasil - Bolívia. 2010. Dissertação (Mestrado em Estudos Comparados sobre as Américas) Universidade de Brasília, Brasília, 2010.

GRANDO, Beleni Saléte. Corpo e educação: as relações interculturais nas práticas corporais Bororo em Meruri. 2004. Tese (Doutorado em Educação) Universidade Federal de Santa Catarina, Florianópolis, 2004.

GRUPIONI, Luís Donisete Benzi. Livros didáticos e fontes de informações sobre as sociedades indígenas no Brasil. In: GRUPIONI, Luís Donisete Benzi; SILVA, A. L. (org.). A temática indígena na escola: novos subsídios para professores de $1^{\circ} \mathrm{e}$ $2^{\circ}$ graus. 2. ed. São Paulo: Editora Global; Brasília: MEC: UNESCO, 1998. p. 481521.

HERMIDA, Antônio José Borges. História do Brasil: 5a série. São Paulo: Companhia Editora Nacional, [19--].

HERNANDEZ, Leila Maria Gonçalves. A África na sala de aula. São Paulo: Selo Negro, 2005.

JESUS, Naine Terena de. Vídeo nas(das) aldeias: o áudio visual e o ensino de história. In: JESUS, Nauk Maria; RIBEIRO, Renilson Rosa; CEREZER, Osvaldo Mariotto (org.). Ensino de história: trajetórias em movimento. Cáceres: Editora Unemat, 2007. p. 97-106.

MACEDO, Joaquim Manuel de. Lições de história do Brasil para uso das escolas de instrucção primaria. 10. ed. Rio de Janeiro: H. Garnier, 1861-1907.

MARTINS, Maria Cristina Bohn. As sociedades indígenas, a história e a escola. Antíteses, Londrina, v. 2, n. 3, p. 153-167, jan./jun. 2009.

MATO GROSSO. Justiça Federal. Ofício n. 1041/2006/SEPOD/EMO.

Comunicando à FUNAI que o Juiz Julier Sebastião da Silva, acata um pedido feito através de liminar onde resguarda a posse que a Comunidade Chiquitano Vila Nova exerce sobre as terras que tradicionalmente ocupam, em área rural do Município de Porto Esperidião. Mato Grosso: Justiça Federal de Mato Grosso: Subseção Judiciária de Cáceres, 2006. 
MATO GROSSO. Justiça Federal. Processo n. 2000.36.01.0011484-2. Fica definido um Módulo Rural do INCRA, definido em 25 ha. Para uso exclusivo dos indígenas, é assegurado o acesso da comunidade em toda área objeto do litígio, ressalvada as instalações da Fazenda São Pedro. Mato Grosso: Justiça Federal de Mato Grosso: Subseção Judiciária de Cáceres, 2008.

MEIRELES, Denise Maldi. Guardiães da fronteira: Rio Guaporé, século XVIII. Petrópolis: Vozes, 1989.

MONTELLATO, Andrea Rodrigues Dias, CABRINI, Conceição; CATELLI JUNIOR, Roberto. História temática: diversidade cultural e conflitos: 6a série. São Paulo: Scipione, 2000.

PACINI, Aloir. Identidade étnica e território Chiquitano na fronteira (BrasilBolívia). 2012. Tese (Doutorado em Antropologia Social) - Universidade Federal do Rio Grande do Sul, Porto Alegre, 2012a.

PACINI, Aloir. Um perspectivismo ameríndio e a cosmologia anímica chiquitana. Espaço Ameríndio, Porto Alegre, v. 6, n. 2, p. 137-177, jul./dez. 2012b.

PILLETI, Nelson; PILLETI, Claudino. História \& vida - Brasil: da pré-história à independência, $1^{\circ}$ grau. 4. ed. São Paulo: Editora Ática, 1991. v. 1.

PINSKY, Jaime. Nação e ensino de história no Brasil. In: PINSKY, Jaime (org.). $O$ ensino de história e a criação do fato. São Paulo: Contexto, 2009. p. 11-26.

QUEIROZ, Leticia Antonia. Educação da criança chiquitano: o Curussé como expressão das práticas corporais e culturais. 2013. Dissertação (Mestrado em Educação) - Universidade Federal de Mato Grosso, Cuiabá, 2013.

RAMINELLI, Ronald. Imagens da colonização: a representação do índio de Caminha a Vieira. Rio de Janeiro: Jorge Zahar Ed., 1996.

RIBEIRO, João. Colônia(s) de identidade(s): discursos sobre a raça nos manuais escolares de história do Brasil. 2004. Dissertação (Mestrado em História Cultural) - Universidade Estadual de Campinas, Campinas, 2004.

RIBEIRO, João. Uma história mal contada. História Viva, São Paulo, n. 14, p. 5459, 2006. Edição especial: mar português.

RIBEIRO, Renilson Rosa. A questão do outro e os livros didáticos. Fato\&Versões, Uberlândia, v. 2, n. 4, p. 75-88, 2010.

ROCHA, Everardo P. Guimarães (org.). Testemunha ocular: textos de antropologia social do cotidiano. São Paulo: Brasiliense, 1984.

SANTOS, Ângela Maria. Vozes e silêncio do cotidiano escolar: análise das relações raciais entre alunos negros e não negros em duas escolas públicas no município de Cáceres. 2006. Dissertação (Mestrado em Educação) - Universidade Federal de Mato Grosso, Cuiabá, 2006. 
SILVA, Joana Aparecida Fernandez et al. Estudo das comunidades indígenas na área de influência do Gasoduto Bolívia-Mato Grosso. Cuiabá, 1998.

SILVA, Adriane Costa. Versões didáticas da história indígena (1870-1950). 2000. Dissertação (Mestrado em Educação) - Universidade de São Paulo. São Paulo, 2000.

SILVA, Giovani José. A presença Camba-Chiquitano na fronteira Brasil-Bolívia (1938-1987): identidades, migrações e práticas culturais. 2009. Tese (Doutorado em História) - Universidade Federal de Goiás, Goiania, 2009.

SILVA, Giovani José. A respeito de migrações e estigmas: indígenas CambaChiquitano na fronteira Brasil-Bolívia, segunda metade do século XX. História Unisinos, São Leopoldo, v. 15, p. 159-171, 2011 a.

SILVA, Giovani José. Perspectivas do ensino de história e diversidade étnicocultural: contribuições a um debate transdiciplinar. In: ZAMBONI, Ernesta; GALZERANI, Maria Carolina Bovério; PACIEVITCH, Caroline (org.). Memória, sensibilidades e saberes. Campinas: Alínea, 2015. p. 52-63.

SILVA, Giovani José. Séculos de história indígena no coração da América do Sul: os Chiquitano no (atual) Oriente Boliviano. Anos 90, Porto Alegre, v. 19, p. 159$186,2011 \mathrm{~b}$.

SILVA, Joana Aparecida Fernandes. Identidades e conflitos na fronteira: poderes locais e os Chiquitano. Memoria Americana, Buenos Aires, v. 16, n. 2, p. 119$148,2008$.

SILVA, Joana Aparecida Fernandes. Pertencimento e identidade, territorialidade e fronteira entre os Chiquitanos no Brasil e na Bolívia. Espaço Ameríndio, Porto Alegre, v. 6, n. 1, p. 119-137, jan./jun. 2012 a.

SILVA, Joana Aparecida Fernandes. Território e fronteiras Brasil - Bolívia no país dos Chiquitanos. Revista do Museu Antropológico, Goiânia, v. 5/6, n. 1, p. 179212, jan./dez. 2012 b.

SILVA, Joaquim. História do Brasil para a primeira série ginasial. 8. ed. São Paulo: Companhia Editora Nacional, 1951.

SILVA, Tomaz Tadeu da. Documentos de identidade: uma introdução às teorias do currículo. 2. ed. Belo Horizonte: Autêntica, 2001.

STAROBINSKI, Jean. As máscaras da civilização. São Paulo: Companhia das Letras, 2001.

TELLES, Norma. Cartografia Brasilis ou essa história está mal contada. 2. ed. São Paulo: Loyola, 1992.

TODOROV, Tzvetan. A conquista da América: a questão do outro. São Paulo: Martins Fontes, 1996. 
ZAMBONI, Ernesta; BERGAMASCHI, Maria Aparecida. Os povos originários na literatura escolar: possibilidades de um discurso intercultural. In: GALZERANI, Maria Carolina; BUENO, João Batista Gonçalves; PINTO JUNIOR, Arnaldo (org.). Paisagens da pesquisa contemporânea sobre o livro didático de história. Campinas: Paco Editorial, 2013. p. 287-306.

Recebido em 30 de Dezembro de 2018 Aprovado em 15 de Abril de 2020 